THIRD-YEAR TECHNICIAN MATHEMATICS AND APPLICATIONS 
Other books in this series

First-year Technician Mathematics: Rhys Lewis

Second-year Technician Mathematics: Rhys Lewis

Books by the same author

Electronic Systems for Radio, Television, and Electronics Mechanics

Books of related interest

Linear Electronic Circuits and Systems: G. D. Bishop

Digital Electronic Circuits and Systems: Noel M. Morris

Essential Formulae for Electronic and Electrical Engineers: Noel M. Morris

Electrical Circuits and Systems: Noel M. Morris

The Electrical Principles of Telecommunications: $R$. Lowe and D. Nave

Basic Electrotechnology: H. Cotton

Semiconductor Devices: Noel M. Morris 


\section{THIRD-YEAR TECHNICIAN MATHEMATICS AND APPLICATIONS}

for Electrical, Electronics and

Telecommunications Students

\section{RHYS LEWIS}

B.Sc. Tech., C. Eng., M.I.E.E.

Principal Lecturer, Openshaw Technical College, Manchester

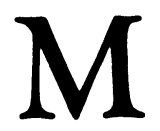


All rights reserved. No part of this publication may be reproduced or transmitted, in any form or by any means, without permission.

First published 1976 by THE MACMILLAN PRESS LTD

London and Basingstoke Associated companies in New York Dublin Melbourne Johannesburg and Madras

SBN 333187075

ISBN 978-0-333-18707-4

ISBN 978-1-349-02696-8 (eBook)

DOI 10.1007/978-1-349-02696-8

Typeset in Great Britain by PREFACE LTD

Salisbury, Wiltshire

This book is sold subject to the standard conditions of the Net Book Agreement.

The paperback edition of this book is sold subject to the condition that it shall not, by way of trade or otherwise, be lent, re-sold, hired out, or otherwise circulated without the publisher's prior consent in any form of binding or cover other than that in which it is published and without a similar condition including this condition being imposed on the subsequent purchaser. 


\section{Contents}

Preface

1 Algebra 1

Further Use of Logarithms

$\begin{array}{ll}\text { Simultaneous Equations } & 7\end{array}$

2 Graphs and the Exponential Function $\quad 17$

$\begin{array}{ll}\text { Review of Basic Principles } & 17\end{array}$

$\begin{array}{ll}\text { Standard Functions } & 18\end{array}$

Graphs of Trigonometric Functions $\quad 20$

Multiple Frequency Curves $\quad 22$

The Exponential Function $\quad 23$

$\begin{array}{ll}\text { General Equation of Exponential Changes } & 27\end{array}$

Combined Trigonometric and Exponential Functions 30

Cartesian and Polar Co-ordinates 33

3 Trigonometry 36

Further Identities $\quad 36$

Double-angle Formulae $\quad 37$

Sum and Difference Formulae $\quad 38$

4 Differentiation $\quad 53$

Rates of Change $\quad 53$

Basic Principles - the Meaning of $\mathrm{d} y / \mathrm{d} x \quad 55$

Differentiation from First Principles $\quad 57$ 
Differentiation by Rule

Differentiating the Function of a Function 65

Products and Quotients of Functions 69

Products of functions - quotients

Differential Coefficient of Exponential Functions 75

Differential Coefficient of Logarithmic Functions 76

Differential Coefficient of Trigonometric Functions 81

5 Integration 86

Constant of Integration $\quad 86$

Some Basic Rules of Integration $\quad 87$

Integration by Substitution $\quad 95$

Determination of Areas 98

Integrating Between Limits: Definite Integrals 99

Average and R.M.S. Values 105

Sinusoidal Functions 105

Half- and Full-wave Rectified Sinusoidal Waveforms 109

6 Complex Numbers 115

Resolution of Vectors into Components 115

$\begin{array}{ll}\text { The operator } j \text { - the Argand diagram } & 121\end{array}$

Addition - subtraction - multiplication - division

Use of $\mathrm{j}$ Notation in Electrical Problems 124

Representation of impedance

Cartesian and Polar Co-ordinates

Multiplication and division of numbers written in polar form obtaining square roots

7 Mathematical Applications 138

Transient Response of D.C. Circuits 138

Capacitance and resistance in a series d.c. circuit - inductance and resistance in a series d.c. circuit

Mathematical Expression of Faraday's Law: the Unit of Self-inductance 143

Mathematical Derivation of Formulae in A.C. Circuits 146

$C R$ circuits - LR circuits

Use of Complex Numbers in A.C. Circuits $\quad 150$

Series circuits - parallel circuits

Applications of Maxima and Minima Theory 155

Efficiency calculations - maximum power transfer theory 
Use of Complex Numbers in the Solution of A.C. Bridge Equations 160

The resistance-ratio bridge - the Maxwell bridge - the Hay bridge

Test Papers

Answers 


\section{Preface}

This book is the third in a series of three covering the mathematics syllabuses of courses leading to Electrical and Electronic Technician and ultimately Technician Engineer status. At the present time these courses include the City and Guilds of London Institute courses 280, 281, 285, 270 and 272 and the titles of the books breaking the syllabuses into four years (the third-year text including mathematical applications) stem from the organisation of these courses. With the advent of the Technician Education Council and subsequent reorganisation of courses it may be found that the breakdown by year will change. However it is anticipated that the total content of all three books will more than adequately cover the total syllabus content of all electrical and electronic technician courses or programmes both present and proposed. All three books contain a large number of examples both worked and otherwise and finish with a number of typical examination papers covering the content of each volume.

The assistance and advice of Mr Noel Morris, the series editor, is gratefully acknowledged. In addition I would particularly like to thank Mrs L. J. E. Jones for typing the manuscript and, as always, my wife for her patience and encouragement during many hours devoted to the preparation of this series. 